\title{
Parmelia barrenoae and $P$. pinnatifida, two lichen species new to some European countries and Turkey
}

\author{
Emilia A. Ossowska \\ Department of Plant Taxonomy and Nature Conservation, Faculty of Biology, University of Gdansk, \\ Wita Stwosza 59, PL-80-308 Gdansk, Poland. \\ E-mail: emilia.ossowska@ug.edu.pl \\ ORCID: 0000-0002-1357-6071
}

\begin{abstract}
The first records of Parmelia barrenoae from Hungary, Slovakia and Sweden and P. pinnatifida from Denmark, Estonia and Turkey are presented.
\end{abstract}

Keywords: Lecanoromycetes, lichenized Ascomycota, parmelioid lichens, species distribution.

\section{INTRODUCTION}

In Europe and adjacent areas, 13 species of Parmelia Ach. have been confirmed based on morphological, chemical and molecular methods (e.g. Feuerer \& Thell, 2002; Molina et al., 2004, 2011; Divakar et al., 2005; Hawksworth et al., 2008, 2011; Thell et al., 2008, 2017; Ossowska et al., 2018, 2019; Corsie et al., 2019; Crespo et al., 2020). The revision of material of two species, Parmelia barrenoae Divakar et al. and $P$. pinnatifida Kurok., yielded that they have never been reported from some countries in Eurasia, what is supplemented in this paper. Notes on both species, including their distribution are provided below.

\section{MATERIALS AND METHODS}

The studied material is housed in B, UGDA, S and TUR herbaria. The secondary lichen compounds were studied by thin-layer chromatography in solvents A and C (Orange et al., 2001). Diagnostic morphological features, important for the identification of $P$. barrenoae (e.g. the shape of rhizines) and $P$. pinnatifida (e.g. the type of pseudocyphellae) were examined under a stereomicroscope.

\section{THE SPECIES}

Parmelia BarRenoae Divakar, M. C. Molina \& A. Crespo

$P$. barrenoae can be distinguished from other sorediate Parmelia species ( $P$. sulcata Taylor and P. encryptata A. Crespo et al.) by its simple to furcate rhizines, short and broad $(2-7 \mathrm{~mm})$, apically rounded, overlapping lobes with soralia arising from linear pseudocyphellae, which rapidly produce soredia (Divakar et al., 2005; Hodkinson et al., 2010; Ossowska \& Kukwa, 2016). This corticolous lichen grows mainly on the bark of deciduous or rarely coniferous trees, and occasionally on rocks (Divakar et al., 2005; Barreno \& Herrera-Campos, 2009). Specimens reported here were found on bark of Quercus spp. and Tilia sp; one specimen was found on rock. Specimens from Hungary and Slovakia were found in oak-hornbeam and oak forests at elevations of c. $260-500 \mathrm{~m}$.

In Europe, $P$. barrenoae has been reported from Belarus, Czech Republic, Italy, Macedonia, Poland, Portugal, Russia and Spain (Divakar et al., 2005; Barreno \& Herrera-Campos, 2009; Paz-Bermúdez et al., 2009; Ravera \& Genovesi, 2012; Šoun et al., 2015; Ossowska \& Kukwa, 2016; Malíček \& Mayrhofer, 2017; Yatsyna, 2020). It has also been noted in Africa (Morocco) and North America (USA) (Hodkinson et al., 2010). Here, it is reported for the first time from Hungary, Slovakia and Sweden.

Specimens examined: HUNGARY. Central Hungary, Pest County, Nagymaros, Pilis Mountains, Hegyes-tetö, alt. c. $470 \mathrm{~m}, 47^{\circ} 47^{\prime} 02.8^{\prime \prime} \mathrm{N}$, $18^{\circ} 56^{\prime} 01.4^{\prime \prime} \mathrm{E}$, oak-hornbeam forest, on Quercus sp., 3 May 2019, leg. U. Schiefelbein 5280 (UGDA L-26591). SLOVAKIA. Banská Bystrica region, Rimavská Sobota district, Hajnáčka, Cerová vrchovina, Ragáč, W of Hajnáčka, alt. c. 
$500 \mathrm{~m}, 48^{\circ} 13^{\prime 2} 22.5^{\prime \prime} \mathrm{N}, 19^{\circ} 58^{\prime} 54.8^{\prime \prime} \mathrm{E}$, Turkey oak forest, on Quercus cerris, 30 Apr. 2019, leg. U. Schiefelbein 5268 (UGDA L-26579); Nitra region, Nové Zámky district, Štúrovo, Burda, Chlaba, northern part of the Burda mountains, $\mathrm{E}$ of Lela, alt. c. $260 \mathrm{~m}, 47^{\circ} 51^{\prime} 22.4^{\prime \prime} \mathrm{N}, 18^{\circ} 47^{\prime} 34.4^{\prime \prime} \mathrm{E}$, oak-hornbeam forest, on Quercus sp., 1 May 2019, leg. U. Schiefelbein 5271 (UGDA L-26587). SWEDEN. Gästrikland: Högbo parish, Sandviken, $500 \mathrm{~m}$ S of Sandviken church, 60 $36.999^{\prime} \mathrm{N}$, $16^{\circ} 47.137^{\prime} \mathrm{E}$, on bark of Tilia sp., 25 Dec. 2016, leg. G. Odelvik 16-723, (S F-316263); Pite Lappmark: Arjeplog parish, Tjidtják, S of Davnastjårro, $66^{\circ} 56.583^{\prime} \mathrm{N}, 16^{\circ} 49.629^{\prime} \mathrm{E}$, saxicolous, 26 Aug. 2017, leg. G. Odelvik 17-152, L. Hedenäs \& M. Westberg (S F-316315); Södermanland: Huddinge parish, Fållan, 450 m E-NE of Tacksägelsekyrkan (Trångsund) church, $150 \mathrm{~m} \mathrm{~S}-\mathrm{SW}$ of house (Solvik), E of Magelungen, $59^{\circ} 13.644^{\prime} \mathrm{N}$, $18^{\circ} 07.386^{\prime} \mathrm{E}$, on bark of Tilia sp., 28 Apr. 2017, leg. G. Odelvik 17-79 (S F-316235).

\section{PARMELIA PINNATIFIDA Kurokawa}

The following characters distinguish $P$. pinnatifida from other Parmelia species without vegetative propagules $(P$. discordans Nyl. and $P$. omphalodes (L.) Ach): narrow, sublinear lobes (1-2 mm broad) with narrow lobules; pseudocyphellae marginal or marginal and laminal, laminal pseudocyphellae mainly connected with the marginal ones (Ossowska et al., 2019). It also differs from $P$. discordans in the production of salazinic acid (protocetraric acid present in the latter) (Ossowska et al., 2019). Parmelia pinnatifida is a saxicolous species mainly inhabiting siliceous rocks, but rarely growing also on bark of trees (Thell et al., 2011; Ossowska \& Kukwa, 2016). Specimens studied here were collected from rocks.

The species is widely distributed in Europe and known from Austria, Czech Republic, Finland, France, Germany, Iceland, Italy, Norway, Poland, Romania, Russia, Slovakia, Spain and Sweden (Hawksworth et al., 2008; Liška et al., 2008; Wirth et al., 2010; Heiðmarsson et al., 2012; Guttová et al., 2013; Ossowska \& Kukwa, 2016; Nimis et al., 2018; Gheza, 2019). Outside Europe, it has been reported from Canada, Greenland and USA (Hawksworth et al., 2008; Esslinger, 2015). The first records of $P$. pinnatifida from Denmark, Estonia and Turkey are presented here. According to recent new data on its morphology and chemistry (especially the type of pseudocyphellae and presence of lobaric acid in some specimens), $P$. pinnatifida would appear to have a wider geographical distribution than current data indicate, as it was not always distinguished from $P$. omphalodes (see also Ossowska et al. 2019).

Specimens examined: ESTONIA. Saaremaa, Kuressaare, NW of Muratsi, 58 14'45.20"N, $22^{\circ} 30^{\prime} 37.39 " \mathrm{E}$, Juniperus and Corylus alvar, saxicolous, 14 June 1935, leg. E. Häyrén (H). DENMARK. Bornholm, Randkløve Skår, saxicolous, 3 July 1987, leg. H. Skult (TUR 69426); Bornholm: Christiansø, maritime rock, 2 July 1987, leg. H. Skult (TUR 69270). TURKEY. Anatolia, north-exposed gneiss rock, near Milas, between Narhisar and Cukurköy, alt. $850 \mathrm{~m}$, $37^{\circ} 29^{\prime} 45.29^{\prime \prime N}, 27^{\circ} 42^{\prime} 55.27^{\prime \prime} \mathrm{E}, 25$ March 1983, leg. V. John (B 600160982).

\section{ACKNOWLEDGEMENTS}

I am greatly indebted to Ulf Schiefelbein (Rostock, Germany) and the curators of B, TUR and S herbaria for sending material for the study, Martin Kukwa (Gdansk, Poland) and two reviewers for reviewing the first version of this manuscript.

\section{REFERENCES}

Barreno, E. \& Herrera-Campos, M. A. 2009. Parmelia barrenoae Divakar, M.C. Molina \& A. Crespo un liquen nuevo para la flora Asturiana. Boletín de Ciencias de la Naturaleza R.I.D.E.A. 50: 333-341.

Corsie, E. I., Harrold, P. \& Yahr, R. 2019. No combination of morphological, ecological or chemical characters can reliably diagnose species in the Parmelia saxatilis aggregate in Scotland. Lichenologist 51: 107-121. https://doi.org/10.1017/ S0024282919000069

Crespo, A., Rico, V. J., Garrido, E., Lumbsch, H. T. \& Divakar, P. K. 2020. A revision of species of the Parmelia saxatilis complex in the Iberian Peninsula with the description of $P$. rojoi, a new potentially relict species. Lichenologist 52: 365-376. https:/ / doi.org/10.1017/S0024282920000341

Divakar, P. K., Molina, M. C, Lumbsch, H. T. \& Crespo, A. 2005. Parmelia barrenoae, a new lichen species related to Parmelia sulcata (Parmeliaceae) based on molecular and morphological data. $L i$ chenologist 37: 37-46. https://doi.org/10.1017/ S0024282904014641

Esslinger, T. L. 2015. A cumulative checklist for the lichen-forming, lichenicolous and allied fungi of the Continental United States and Canada. (First posted 
1 December 1997, most recent version (\#20) 19 April 2015). - Fargo: North Dakota State University: http://www.ndsu.edu/pubweb/ esslinge/ chcklst/chcklst7.htm.

Feuerer, T. \& Thell, A. 2002. Parmelia ernstiae - a new macrolichen from Germany. Mitteilungen aus dem Institut für Allgemeine Botanik in Hamburg 30-32: 49-60.

Gheza, G. 2019. The macrolichens of Val di Scalve (northern Italy) and the first record of Parmelia pinnatifida in Italy. Webbia 74: 307-315. https: / / doi.org/10.1080/00837792.2019.1692595

Guttová, A., Lackovičová, A. \& Pišút, I. 2013. Revised and updated checklist of lichens of Slovakia. Biologia 68: 845-850. https://doi.org/10.2478/ s11756-013-0218-y

Hawksworth, D. L., Blanco, O., Divakar, P. K., Ahti, T. $\&$ Crespo, A. 2008. A first checklist of parmelioid and similar lichens in Europe and some adjacent territories, adopting revised generic circumscriptions and with indications of species distributions. Lichenologist 40: 1-21. https://doi.org/10.1017/ S0024282908007329

Hawksworth, D. L., Divakar, P. K., Crespo, A. \& Ahti, T. 2011. The checklist of parmelioid and similar lichens in Europe and some adjacent territories: additions and corrections. Lichenologist 43: 639645. https://doi:10.1017/S0024282911000454

Heiðmarsson, S., Alstrup, V., Högnabba, F., Motiejūnaitè, J., Nordin, A., Pykälä, J., Suija, A., Timdal, E. \& Westberg, M. 2012. Floristic news from the NLF Iceland excursion 2009. Graphis Scripta 24: 19-25.

Hodkinson, B. P., Lendemer, J. C. \& Esslinger, T. L. 2010. Parmelia barrenoae, a macrolichen new to North America and Africa. North American Fungi 5(3): 1-5. https://doi.org/10.2509/ naf2010.005.003

Liška, J., Palice, Z. \& Slavíková, Š. 2008. Checklist and Red List of lichens of the Czech Republic. Preslia 80: 151-182.

Malíček, J. \& Mayrhofer, H. 2017. Additions to the lichen diversity of Macedonia (FYROM). Herzogia 30: 431-444. https://doi.org/0.13158/ heia.30.2.2017.431

Molina, M. C., Crespo, A., Blanco, O., Lumbsch, H. T. \& Hawksworth, D. L. 2004. Phylogenetic relationships and species concepts in Parmelia s. str. (Parmeliaceae) inferred from nuclear ITS rDNA and $\beta$-tubulin sequences. Lichenologist 36: 37-54. https://doi.org/10.1017/S0024282904013933

Molina, M. C., Divakar, P. K., Millanes, A. M., Sanchez, E., Del-Prado, R., Hawksworth, D. L. \& Crespo, A. 2011. Parmelia sulcata (Ascomycota: Parmeliaceae), a sympatric monophyletic species complex. Lichenologist 43: 586-601. https:/ / doi. org/10.1017/S0024282911000521

Nimis, P. L., Hafellner, J., Roux, C., Clerc, P., Mayrhofer, H., Martellos, S. \& Bilovitz, P. O. 2018. The lichens of the Alps - an annotated checklist.
MycoKeys 31: 1-634. https://doi.org/10.3897/ mycokeys.31.23568

Ossowska, E. \& Kukwa, M. 2016. Parmelia barrenoae and $P$. pinnatifida, two lichen species new to Poland. Herzogia 29: 198-203. https://doi. org/10.13158/heia.29.1.2016.198

Ossowska, E., Guzow-Krzemińska, B., Dudek, M., Oset, M. \& Kukwa. M. 2018. Evaluation of diagnostic chemical and morphological characters in five Parmelia species (Parmeliaceae, lichenized Ascomycota) with special emphasis on the thallus pruinosity. Phytotaxa 383: 165-180. https://doi. org/10.11646/phytotaxa.383.2.3

Ossowska, E., Guzow-Krzemińska, B., Kolanowska, M., Szczepańska, K. \& Kukwa, M. 2019. Morphology and secondary chemistry in species recognition of Parmelia omphalodes group - evidence from molecular data with notes on the ecological niche modelling and genetic variability of photobionts. MycoKeys 61: 39-74. https://doi.org/10.3897/ mycokeys.61.38175

Orange, A., James, P. W. \& White, F. J. 2001. Microchemical methods for the identification of lichens. British Lichen Society, London. 101 pp.

Paz-Bermúdez, G., López de Silanes, M. E., Terrón, A., Arroyo, R., Atienza, V., Brime, S. F., Burgaz, A. R., Carvalho, P., Figueras, G., Llop, E., Marcos, B., Pino-Bodas, R., Prieto, M., Rico, V. J., Férnandez-Salegui, A. B. \& Serińá, E. 2009. Lichens and lichenicolous fungi in the Montesinho Natural Park, the Serra da Nogueira and the Rio Sabor Valley (Portugal). Cryptogamie, Mycologie 30: 279-303.

Ravera, S. \& Genovesi, V. 2012. Studia Lichenologica in Italia Centrale. VIII. Specie nuove ed interessanti per la Regione Molise. Notiziario della Società Lichenologica Italiana 25: 67.

Šoun, J., Vondrák, J. \& Bouda, F. 2015. Rare and little known species in the Třebič Region and its surroundings. Bryonora 56: 1-23.

Thell, A., Elix, J. A., Feuerer, T., Hansen, E. S., Kärnefelt, I., Schüler, N. \& Westberg, M. 2008. Notes on the systematics, chemistry and distribution of European Parmelia and Punctelia species (lichenized ascomycetes). Sauteria 15: 545559.

Thell, A., Thor, G. \& Ahti, T. 2011. Parmelia. In: Thell, A. \& Moberg, R. (eds). Nordic Lichen Flora. Volume 4. Parmeliaceae. Nordic Lichen Society, Uddevalla. Pp. 83-90.

Thell, A., Tsurykau, A., Persson, P. E., Hansson, M., Åsegård, E., Kärnefelt, I. \& Seaward, M. R. D. 2017. Parmelia ernstiae, $P$. serrana and $P$. submontana, three species increasing in the Nordic countries. Graphis Scripta 29: 24-32.

Wirth, V., Hauck, M., Brackel, W. von, Cezanne, R., de Bruyn, U., Dürhammer, O., Eichler, M., Gnüchtel, A., Litterski, B., Otte, V., Schiefelbein, U., Scholz, P., Schultz, M., Stordeur, R., Feuerer, T., Heinrich, D. \& John, V. 2010. Checklist of lichens 
and lichenicolous fungi in Germany. Version \#2: 19 January 2011. Göttingen: Georg August University of Göttingen: http://www.gwdg.de/ $\sim$ mhauck
Yatsyna, A. P. 2020. The lichen genus Parmelia Ach. in Belarus. Raznoobrazie rastitel'nogo mira 1(4): 5-16. (In Russian). https://doi. org/ 10.22281/2686-9713-2020-1-5-16 